Al Qalam: Jurnal Ilmiah Keagamaan dan Kemasyarakatan

https://jurnal.stiq-amuntai.ac.id/index.php/al-qalam

P-ISSN: 1907-4174; E-ISSN: 2621-0681

DOI : 10.35931/aq.v16i2. 903

\title{
PENGEMBANGAN MODEL PEMBELAJARAN PASCA COVID-19 BERDASARKAN PEMBELAJARAN ABAD 21
}

\author{
Ridhatullah Assya'bani \\ Sekolah Tinggi Ilmu Al-Qur'an (STIQ) Amuntai \\ rassyabani@gmail.com \\ Muhammad Majdi \\ Sekolah Tinggi Ilmu Al-Qur'an (STIQ) Amuntai \\ muhammadmajdi755@gmail.com
}

\begin{abstract}
Abstrak
Pembuatan tugas jurnal ini dilakukan oleh keadaan situasi dan kondisi selama pasca periode Pandemi Covid-19. Dalam proses pembelajaran atau aktivitas yang menuntut semua orang untuk melakukan aktivitas maupun kegiatan di rumah masing-masing. Dalam implikasinya kegiatan pembelajaran tentu memerlukan dan menggunakan pembelajaran sistem online, untuk memastikan bahwa pendidikan berlangsung dengan baik menggunakan sistem online ini yang mana berhubungan dengan pembelajaran era abad 21 yang ditandai dengan pemenfaatan teknologi informasi dan komunikasi pada segala aspek kehidupan, termasuk dalam kegiatan pembelajaran. Maka yang diperlukan metode penelitian dalam pembuatan jurnal ini adalah studi pustaka dan penemuan jurnal ilmiah dengan fokus pada tujuan untuk menemukan dan mengembangkan model pembelajaran yang sesuai dan efektif serta yang bisa digunakan dalam proses pendidikan pasca Covid-19. Beberapa Hasil di temukan dalam penelitian dan pembuatan jurnal ini diharapkan bisa memberikan perkembangan model pembelajaran online seperti apa yang baik dan efektif dipergunakan oleh Guru maupun Dosen pembimbing. Tujuan memberikan Perkembangan model pembelajaran ini supaya dalam proses pendidikan menjadi efesien, antusias, efektif dan berkualitas. Pasca pandemi Covid-19 di Indonesia pada pertengahan Maret 2020 lalu, pemerintah daerah mengeluarkan dan memberikan kebijakan, salah satunya di bidang pendidikan. Kebijakan ini untuk sementara membatalkan atau mehilangkan proses pengajaran yang belajar mengajar tatap muka pada biasanya, dan sekarang perlu belajar melalui sistem pembelajaran online di tingkat dasar, Menengah dan Universitas. Korelasi model Pembelajaran Abad 21 yang relevan Pasca Covid-19 adalah 1) Communication skill, 2) Collaboration skill, dan 3) Critical thinking and problem solving skill.
\end{abstract}

Kata Kunci: Model pembelajaran, Pasca Covid-19, Pembelajaran Abad 21.

\section{PENDAHULUAN}

Saat ini, dunia kita sedang disibukkan dengan munculnya masa pandemi virus corona Covid-19. Berbagai cara dan upaya yang telah dilakukan pemerintah untuk menghilangkan penularan virus Corona ini, termasuk yang dikeluarkannya Peraturan Pemerintah Tahun 2020, Nomor 21 yang menyangkut percepatan penanganan Covid-19. Pembatasan sosial skala besar dalam konteks 19 telah menyebabkan pembatasan berbagai kegiatan termasuk sekolah.

Al Qalam: Jurnal Ilmiah Keagamaan dan Kemasyarakatan Vol. 16, No. 2

Maret - April 2022 
Ridhatullah Assya'bani, Muhammad Majdi : Pengembangan Model Pembelajaran Pasca Covid-19 Berdasarkan Pembelajaran Abad 21

Bersamaan dengan itu, kegiatan home learning (BDR) diumumkan secara resmi melalui pengumuman.

Bela Dina menjelaskan bahwa Menteri Pendidikan dan Kebudayaan Nomor 36962 / MPK.A / HK / 2020 tentang pendidikan pembelajaran sistem online dan beraktivitas di rumah untuk mencegah terjangkitnya penyakit virus corona. Tindakan ini membuat tenaga pendidik dan siswa harus terus bekerja dan belajar di rumah dari sekolah dasar hingga universitas perguruan tinggi. ${ }^{1}$ Kebijakan ini tidak hanya akan mempengaruhi hubungan guru dan murid selama belajar dari rumah, tetapi juga pentingnya mengoptimalkan bantuan wali siswa dalam melaksanakan belajar dari rumah. Kebijakan pembelajaran keluarga telah menyebabkan pembelajaran dilakukan secara online. Mereka tidak bisa bertatap muka karena ini untuk menghentikan penyebaran Covid19. Istilah pembelajaran online adalah kependekan dari "online".

Sementara itu menjelaskan kementerian pendidikan dan budaya menyatakan bahwa prinsip dari pembelajaran abad 21 menitik beratkan pada kemampuan siswa dalam pencarian ilmu dari berbagai sumber terkait, merumuskan permasalahan, berpikir analisis dan kerjasama secara sinergi dalam menyelsaikan masalah. Beberapa kendala harus disiapkan dalam mempengaruhi Pembelajaran, khususnya di era pandemi virus Corona ini, diwajibkan seluruh tenaga pendidik untuk melaksanakan kewajiban mengajar di rumah melalui sistem jaringan online. Termasuk beraktivitas di dalam, belajar di dalam rumah, dan mengajar di dalam rumah sudah tidak asing lagi bagi kita, karena pemerintah telah menetapkan peraturan perundang-undangan yang mengatur mengharuskan melakukan aktivitas pendidikan tidak lagi dilakukan di sekolah maupun di kampus seperti biasanya, tetapi kegiatan tersebut di laksanakan secara online yang telah ditentukan pemerintah. Wabah virus Corona ini membuat semua orang melakukan hal-hal kebiasaan dengan menerapkan berbagai prosedur pencagehan penularan virus seperti evakuasi sosial, evakuasi fisik, cuci tangan, menggunakan masker, dan lain sebagainya. Di dalam proses belajar mengajar di dunia pendidikan juga sudah mengalami perubahan, perbedaan yang sangat luar biasa dari sebelumnya. ${ }^{2}$

Sementara itu, perubahan dramatis di bidang pendidikan mulai mengalami perubahan revolusioner. Pembelajaran yang sebelumnya didominasi pembelajaran tatap muka harus beralih ke pembelajaran sistem online di seluruh jenjang pendidikan, termasuk lembaga pendidikan perguruan tinggi, ada juga di didunia pendidikan beberapa yang harus dilakukan dalam pencegahan penularan Virus pada masa pandemi ini, serta banyak kebijakan tentang pendidikan.

\footnotetext{
${ }^{1}$ Nur Atiqoh Bela Dina. Lia, RESPON ORANG TUA TERHADAP PEMBELAJARAN DARING PADA MASA PANDEMI COVID-19, THUFULI: Jurnal Ilmiah Pendidikan, Islam Anak Usia Dini, Volume 2 Nomor 1 Tahun 2020. Hlm. 45.

2Daryanto dan Syaiful Karim, Pembelajaran Abad 21, (Yogyakarta: Gava Media, 2017), hlm. 2.
}

Al Qalam: Jurnal Ilmiah Keagamaan dan Kemasyarakatan Vol. 16, No. 2

$$
\text { Maret - April } 2022
$$


Ridhatullah Assya'bani, Muhammad Majdi : Pengembangan Model Pembelajaran Pasca Covid-19 Berdasarkan Pembelajaran Abad 21

Mengenai Surat yang diberikan dan di edar pada Nomor 3, Tahun 2020 yang telah di keluarkan oleh menteri Pendidikan dan menteri Kebudayaan masalah Pencegahan penularan virus Corona di dunia Pendidikan dan Surat Edaran Nomor 36926 / MPK.A/ HK/ 2020 masalah Pembelajaran menggunakan sistem Online diharapkan dapat memberikan siswa dengan pembelajaran yang menarik. Proses pembelajaran. Pada level ketiga, surat edaran tersebut memiliki muatan yang sama yaitu penerapan pembelajaran online di kampus. ${ }^{3}$

Bagi Widyaningrum menjelaskan pada masa pandemi ini belum ada tempat yang ditemukan untuk menghentikannya. Namun demikian, berbagai analisis, pembahasan dan laporan telah banyak melakukan analisis terhadap cakupan, skala dan keparahan masalah besar ini. Penyusunan jadwal kelas merupakan kegiatan yang sangat perlu dilakukan sekolah untuk menunjang kelangsungan kegiatan pembelajaran (Silvi Destriana Widyaningrum, 2020:306). Biasanya dalam penyusunan kegiatan pembelajaran yang dilaksanakan oleh sekolah disusun sesuai dengan penerapan kalender pendidikan yang ditetapkan oleh pemerintah. Hal ini dilakukan agar instruksi yang diberikan tidak salah paham selama proses persiapan. Oleh karena itu, dalam proses ini diperlukan metode yang tepat untuk mempersiapkan kegiatan pembelajaran.

juga menjelaskan pelaksanaan tugas di kelas dalam kegiatan pendidikan dengan cara jaringan online ini, akan muncul beberapa tanggapan mengenai pendidikan secara luas oleh para praktisi pendidikan (Purim Marbun, 2020 : 129-130). Menteri Pendidikan dan Kebudayaan di Indonesia menanggapi masalah tersebut adalah dengan kebijakannya membatalkan kegiatan ujian nasionall dan menggantinya dengan ujian sekolah, memperpanjang masa berlaku sertifikasi tersier, dan menerbitkan petunjuk belajar untuk tahun ajaran 2020/2021.

Pada masa pandemi ini tidak diragukan lagi telah membuat metode dan desain kegiatan belajar mengajar yang ada. Dalam Penelitian yang dikemukakan oleh Ahmad Rusdiana dan kawan-kawan menyatakan bahwa, selama periode masa pandemi ini pembelajaran rutin mengalami perubahan, salah satunya guru, dosen, dan mahasiswa harus paham dengan kegiatan belajar mengajar secara online. Dalam penelitian ini dikatakan bahwa selama periode covid-19, dosen didorong untuk mengadopsi model pembelajaran yang berpusat pada mahasiswa. Membatasi pertemuan antara dosen dan mahasiswa memerlukan kreativitas dan inovasi dalam merancang model pembelajaran. Sebelum merebaknya Covid-19, orang sudah lama mengenal model pembelajaran online, apalagi terkena dampak globalisasi dan kehancuran. Tjandra mengatakan, teknologi sudah menjadi keseharian manusia. Dalam dunia pembelajaran, istilah Industrial Age 4.0 memungkinkan semua pendidikan, termasuk salah satunya pelajar,

${ }^{3}$ Widya Sari dkk, Jurnal ANALISIS KEBIJAKAN PENDIDIKAN TERKAIT IMPLEMENTASI PEMBELAJARAN JARAK JAUH PADA MASA DARURAT COVID 19, 2020. HIm. 2.

Al Qalam: Jurnal Ilmiah Keagamaan dan Kemasyarakatan Vol. 16, No. 2 Maret - April 2022 
Ridhatullah Assya'bani, Muhammad Majdi : Pengembangan Model Pembelajaran Pasca Covid-19 Berdasarkan Pembelajaran Abad 21

menggunakan berbagai teknologi sebagai media yang di lakukan proses pembelajaran. Teknologi tidak terlepas dari dunia pendidikan, guru atau dosen juga pun harus terbiasa dengan menggunakannya karna dalam belajar mengajar harus menggunakan sistem pembelajaran online.

Pembelajaran abad 21 menawarkan beberapa keunggulan pembelajaran yang dapat dikolaborasikan pada masa pandemi. Hal ini tentunya harus sejalan dengan semua pihak yang terkait untuk mensukseskan pembelajaran yang efektif dan efisien. Beberapa layanan edukasi online dilakukan dengan menggunakan berbagai mecam aplikasi, seperti zoom, Google Classroom, webex meeting, dll. Dapat digunakan sesuai kebutuhan pribadi. Aplikasi ini dirancang untuk mendistribusikan bahan ajar kepada siswa. Keunggulan aplikasi tetap memberikan kesempatan untuk menghubungkan antara para dosen dan mahasiswa, meskipun mereka sedang online. ${ }^{4}$ Juri mengatakan Google Classroom merupakan model pembelajaran gabungan yang dirancang untuk mempermudah pendistribusian pembelajaran.Layanan berbasis internet merupakan sistem e-learning yang dirancang untuk dosen yang dapat berbagi materi secara paperless. Dengan menggunakan teknologi dalam pembelajaran, seseorang dapat berharap untuk memastikan penyampaian pembelajaran secara efektif. Yang berasaskan pembelajaran abad 21.

\section{METODE PENELITIAN}

Pembelajaran online selama semua periode pendidikan formal selama pandemi merupakan upaya untuk meningkatkan kesadaran akan penyebaran virus Covid-19. Karena itu, pemerintah mengeluarkan kebijakan yang mewajibkan belajar dari rumah. Kalaupun belajar di rumah itu wajib, kegiatan belajar harus tetap dilakukan. Ini tidak akan memiliki efek retrospektif pada kinerja pendidik dalam tugasnya (Jamaludin dkk, 2020:91-92). ${ }^{5}$ Proses pembelajaran di rumah maupun online sangat mempengaruhi proses pembelajaran, proses evaluasi, menurunkan kualitas lulusan dan mengurangi evaluasi publik terhadap lulusan. Walaupun dengan pembelajaran online masih banyak kendala yang dihadapi, namun pendidik harus mampu menguasai teknologi informasi agar dapat berinovasi dalam pembelajaran. Namun di sisi lain, sarana dan prasarana penunjang pembelajaran juga harus tersedia dengan baik agar proses pembelajaran dapat berfungsi sesuai dengan yang diharapkan.

Metode penelitian yang digunakan adalah metode kualitatif deskriptif atau bisa juga disebut dengan menggambarkan. Jenis penelitian metode deskriptif ini didasarkan yang bertujuan untuk mendeskripsikan fakta, karakteristik, dan hubungan antar khusus yang diteliti (yang

\footnotetext{
${ }^{4}$ Purim Marbun, Disain Pembelajaran Online Pada Era Dan Pasca Covid-19 Online Learning Design In Era And Post Covid-19, CSRID Journal, Vol. 12 No. 2 Juni 2020. Hlm. 130.

${ }^{5}$ Jamaludin dkk, Belajar dari Covid-19 Perspektif Sosiologi, Budaya, Hukum kebijakan dan Pendidikan, Mesdan, 2020. Hlm. 92.
}

Al Qalam: Jurnal Ilmiah Keagamaan dan Kemasyarakatan Vol. 16, No. 2

Maret - April 2022 
Ridhatullah Assya'bani, Muhammad Majdi : Pengembangan Model Pembelajaran Pasca Covid-19 Berdasarkan Pembelajaran Abad 21

termasuk kata hubungan ini adalah antara aktivitas, pendapat, sikap dan proses yang sedang dibentuk). Dampak kejadian dan fenomena, atau penentuan saluran distribusi gejala atau hubungan tertentu antara penyebab lainnya.

Metode penelitian kualitatif juga menjadi metode yang akan digunakan dalam penelitian ini. Jenis penelitian kualitatif ini adalah penelitian deskriptif dan cenderung menggunakan analisis. Landasan teori menjadi pedoman agar fokus penelitian sejalan dengan fakta di lapangan. Selain itu landasan teori juga dapat digunakan untuk memberikan gambaran tentang latar belakang penelitian dan sebagai bahan pembahasan hasil penelitian. Jenis metode penelitian yang digunakan adalah metode deskriptif, yaitu metode yang meneliti keadaan kerumunan, objek, kondisi, sistem berpikir, atau kategori kejadian terkini. Tujuan dari penelitian deskriptif ini adalah untuk mendeskripsikan, mendeskripsikan atau mendeskripsikan secara akurat fakta, karakteristik dan hubungan, sistem, fakta dan fakta dari fenomena yang diteliti.

Data yang digunakan dalam metode penelitian ini adalah kualitatif. Metode penelitian didasarkan pada data kualitatif merupakan data dalam bentuk non digital atau digital, sehingga hanya berupa data berupa pernyataan atau kalimat. Penelitian pustaka adalah enelitian menggunakan bahan tertulis atau literatur yang ada termasuk hasil penelitian sebelumnya. Penelitian ini biasanya digunakan untuk mempelajari cerita sejarah dan pandangan atau pendapat tokoh.

Widya Sari halaman 3 dalam jurnalnya menjelaskan Jenis metode deskriptif adalah studi pustaka, studi pustaka Merupakan kegiatan mengamati berbagai dokumen yang terkait dengan pokok persoalan. Buku, makalah atau tulisan ini bermanfaat dalam beberapa bentuk dan dapat digunakan sebagai pedoman dalam proses penelitian. Menurut "Pengenalan Metodologi Penelitian Sosial" Kartini Kartono, tujuan penelitian perpustakaan adalah mengumpulkan data dan informasi dengan bantuan berbagai bahan di perpustakaan, dan menggunakan hasilnya sebagai dasar fitur dan alat utama praktik penelitian di bidang ini. . Karena dengan menggunakan studi pustaka artinya sumber datanya diperoleh dari berbagai sumber data terkait dengan topik yang diajukan yaitu pembelajaran jarak jauh pada keadaan darurat Covid-19. ${ }^{6}$

Guru atau dosen merupakan bagian penting untuk mempengaruhi peserta didik dan mahasiswa agar memperoleh prestasi belajar yang maksimal. ${ }^{7}$ Dalam proses pembelajaran di kelas, kedekatan hubungan guru atau dosen dengan peserta didik dan mahasiswa di luar kelas sangat penting untuk mempengaruhi kinerja akademik peserta didik dan mahasiswa. Kinerja

${ }^{6}$ Widya Sari dkk,..., hlm. 3 .

${ }^{7}$ Limbong. Albinur, Pengaruh Model Pembelajaran Daring Akibat Pandemi Covid-19 Terhadap Prestasi Belajar Mahasiswa UNAI pada Semester Genap 2019/2020, Jurnal TeIKa, Volume 10, Nomor 2, Oktober 2020. Hlm. 163.

Al Qalam: Jurnal Ilmiah Keagamaan dan Kemasyarakatan Vol. 16, No. 2

$$
\text { Maret - April } 2022
$$


Ridhatullah Assya'bani, Muhammad Majdi : Pengembangan Model Pembelajaran Pasca Covid-19 Berdasarkan Pembelajaran Abad 21

akademik juga akan dilakukan oleh metode pembelajaran yang digunakan oleh guru maupun yang di lakukan dosen. Oleh karena itu guru atau dosen harus menggunakan mengembangkan metode yang baik dan benar agar pembelajaran menyenangkan dan dapat dipahami oleh murid dan mahasiswa. Hal ini sesuai dengan peranan guru abad 21 yang mampu dan dapat melaksanakan pembelajaran yang berasaskan epar pilar belajar yaitu 1) learning to know, 2) Learning to do, 3) Learning to be, dan 4)Learning to live together.

\section{HASIL DAN PEMBAHASAN}

Pengembangkan model pembelajaran dalam proses belajar mengajar merupakan suatu proses maupun modus sistematis yang dapat di pergunakan untuk memandu pencapaian tujuan pembelajaran, yang meliputi di antaranya; materi, strategi, metode, media, teknik dan alat penilaian pembelajaran. Pendidikan merupakan hal terpenting dalam hidup kita, artinya setiap orang Indonesia berhak atas pendidikan dan harapannya untuk terus berkembang di dalamnya. ${ }^{8}$ Secara umum, pendidikan mengacu pada proses kehidupan mengembangkan diri setiap orang untuk hidup dan terus hidup. Oleh karena itu sangat penting untuk dididik, kita dididik untuk berguna bagi nusa, nusa dan bangsa. Sebelum melaksanakan proses pembelajaran, hal pertama yang harus dilakukan adalah merancang kurikulum pembelajaran. Perlu mempertimbangkan perencanaan yang matang dengan mempertimbangkan setiap aspek umum atau khusus yang berdampak baik. Rencana menghasilkan contoh akan mengimplementasikan proses pembelajaran dalam bentuk model pembelajaran yang inovatif dan kreatif sesuai kebutuhan kelas.

Setelah pandemi masuk ke Indonesia, negara tersebut mengurangi jumlah pasien Covid 19 pada bulan Maret 2020, sehingga pemerintah, provinsi dan daerah merumuskan ketentuan di bidang pendidikan, yang untuk sementara waktu menghilangkan pembelajaran tatap muka, dan di sekolah dan Pembelajaran online. ${ }^{9}$ Pengembangan di universitas hal tersebut bertujuan untuk mendukung penyelenggaraan pendidikan agar perguruan tinggi dapat memberikan layanan informasi yang lebih baik kepada masyarakat di dalam maupun di luar perguruan tinggi melalui internet. Layanan pendidikan lain yang dapat dilaksanakan melalui internet adalah dengan menyediakan materi kursus online yang dapat diakses dan dipergunakan oleh siapa saja yang membutuhkan.

Memperhatikan berbagai kekurangan selama pandemi covid-19 ini, banyak yang dilakukan membuat strategi ataupun mengembangkan model pembelajaran dalam pendidikan untuk kemajuan yang akan mendatang dengan jangka yang panjang mulai dilihat dari kualitas

\footnotetext{
${ }^{8}$ Widya Sari dkk, ..., Hlm. 4.

${ }^{9}$ Yulita Pujilestari, Dampak Positif Pembelajaran Online Dalam Sistem Pendidikan Indonesia Pasca Pandemi Covid-19, Volume 4 Nomor 1 2020. Hlm. 53.
}

Al Qalam: Jurnal Ilmiah Keagamaan dan Kemasyarakatan Vol. 16, No. 2 Maret - April 2022 
Ridhatullah Assya'bani, Muhammad Majdi : Pengembangan Model Pembelajaran Pasca Covid-19 Berdasarkan Pembelajaran Abad 21

guru yang mengajar, kelengkapan setiap jurusan, ketersediaan fasilitas jaringan internet hingga minimnya bantuan kepada siswa. ${ }^{10}$ Dalam proses pasca pandemi tentunya tidak akan sama kehidupan seperti sebelum-sebelumnya. Mulai dari kebiasaan yang baru tersebut, akan menjadikan suatu budaya adat istiadat di dalam kehidupan masyarakat, dari kebiasaan hal-hal hidup bersih, literasi yang teknis dan fleksibilitas dalam proses pembelajaran belajar mengajar. Maka dari itu Keterampilan yang diharapkan pada pembelajaran abad 21 adalah 1) life and career skills, 2) learning and innovation skills, 3) Information media and technology skills. Ketiga keterampilan ini termasuk dari skema pelangi keterampilan-pengetahuan Abad 21 dari Trilling dan Fadel.

Life and career skills (keterampilan hidup berkarir) terdiri dari a) kepemimpinan dan tanggung jawab, b) interaksi sosial dan budaya, c) Fleksibel dan adaptasi, d) Inisiatif dan pengaturan diri, e)Produktivitas dan akuntabilitas. Learning and Innovation (keterampilan belajar dan berinovasi) terdiri dari a) kreatif dan inovasi, b) kritis dan pemecahan masalah, c) komunikasi dan kolaborasi. Information Media and Technology Skills (Keterampilan teknologi dan media informasi)terdiri dari a) literasi informasi, b) literasi teknologi informasi dan komunikasi, c) literasi media. ${ }^{11}$

Menghadapi Revolusi Industri 4.0, guru menghadapi masalah yang sangat sulit karena harus mendidik siswa sesuai masa kini dan masa depan. Guru harus melakukan penelitian tentang teknologi media dan informatika. ${ }^{12}$ Dalam kegiatan pembelajaran guru, belajar dan memahami teknologi informasi bukanlah tugas yang mudah, karena guru berada pada posisi yang nyaman, sehingga tidak memiliki kemampuan belajar mandiri. Institusi pendidikan menjadi pengguna utama model pembelajaran virtual dengan kemampuan pembelajaran jarak jauh, terutama dalam menghadapi pandemi Covid 19.

Pembelajaran virtual berkontribusi pada upaya peningkatan kualitas dan efektivitas pembelajaran. Beberapa syarat penggunaan internet dalam pembelajaran antara lain akses internet tidak menjadi masalah, peserta didik mampu belajar dimana dan kapan saja sesuai dengan kecepatan dan kondisi belajarnya. ${ }^{13}$ Selain itu, melalui penggunaan internet siswa dapat mengakses secara luas berbagai sumber pembelajar yang telah tersedia, dan siswa dapat berinteraksi dengan siswa lainnya. Mentor atau kesempatan untuk pembelajaran komunitas dan

\footnotetext{
${ }^{10}$ Budi Indrawat, Tantangan Dan Peluang Pendidikan Tinggi Dalam Masa Dan Pasca Pandemi Covid-19, Jurnal Kajian Ilmiah (JKI) e-ISSN: 2597-792X, ISSN: 1410-9794 Edisi Khusus No. 1 Juli 2020. Hlm. 46.

${ }^{11}$ Daryanto dan Syaiful Karim, Pembelajaran Abad 21, (Yogyakarta: Gava Media, 2017), hlm. 14.

${ }^{12}$ Sunarsi. Denok, dkk, Pembelajaran Online Dalam Masa Pandemik Covid 19, Jurnal IMPLEMENTASI 2020. HIm. 411.

${ }^{13}$ Sunarsi. Denok, dkk, ..., Hlm. 413.
}

Al Qalam: Jurnal Ilmiah Keagamaan dan Kemasyarakatan Vol. 16, No. 2 Maret - April 2022 
Ridhatullah Assya'bani, Muhammad Majdi : Pengembangan Model Pembelajaran Pasca Covid-19 Berdasarkan Pembelajaran Abad 21

interaksi dengan sumber belajar lainnya. Jeram mencontohkan, siswa yang pendiam di kelas sering menyumbangkan ide dalam diskusi online atau pembelajaran jarak jauh, yang saya sebut Penjaja. Namun pada kenyataannya pembelajaran virtual isasi tidak semudah yang dibayangkan, hal ini terkait dengan masalah akses internet (misalnya jaringan listrik tidak tersedia Masalah jaringan listrik, masalah pembelian listrik dan lain-lain, banyak kita jumpai di daerah terpencil, disisi lain siswa dituntut untuk mengatur proses pembelajaran. Di sini, pelatihan dan dukungan teknis harus disediakan untuk guru dan siswa, dan dukungan untuk desain pembelajaran.

Sebagian besar pengaruh siswa ataupun mahasiswa terhadap proses pendidikan yang di lakukan selama di rumah masa pandemi dengan sistem online ini adalah mereka merasa terpaksa untuk belajar dari jarak yang lumayan jauh tanpa adanya sarana dan prasarana yang memadai bagi siswa maupun mahasiswa tersebut. Dalam kegiatan belajar mengajar tentu fasilitas ini sangat penting dan diharuskan untuk kelancaran kegiatan proses pengajaran, karena dengan fasilitas dan peralatan yang lengkap untuk pembelajaran online dirumah, seperti laptop, komputer atau handphone harus disediakan terlebih dahulu, yang akan memudahkan siswa dalam mendengarkan proses pengajaran online. Kendala selanjutnya dikarenakan siswa belum memiliki budaya belajar jarak jauh, karena selama ini sistem pembelajaran dilakukan secara tatap muka, dan siswa terbiasa berinteraksi dengan teman di sekolah, bermain dan bercanda dengan teman, serta berkomunikasi tatap muka dengan guru. Metode pembelajaran jarak jauh membuat siswa membutuhkan waktu untuk beradaptasi dan menghadapi perubahan baru, yang secara tidak langsung akan mempengaruhi kemampuan belajarnya. Beberapa guru senior tidak dapat memanfaatkan sepenuhnya peralatan atau fasilitas untuk mendukung kegiatan pembelajaran online, sehingga perlu memberikan bantuan dan pelatihan terlebih dahulu. Kemampuan guru untuk menggunakan teknologi akan terpengaruh.

Kualitas rencana kurikulum, atau rencana implementasi sistem pembelajaran online guru, membutuhkan pelatihan terlebih dahulu. Dengan tidak adanya sarana dan prasarana yang memadai di rumah, apa dampak guru terhadap proses pengajaran online di rumah? Fungsi ini sangat penting untuk kelancaran proses pengajaran. Untuk sistem pembelajaran online di rumah sebaiknya disediakan laptop, komputer atau handphone terlebih dahulu, yang akan memudahkan guru dalam memberikan bahan ajar secara online. Kendala selanjutnya adalah guru belum memiliki budaya pembelajaran jarak jauh, karena selama ini sistem pembelajaran telah diterapkan secara tatap muka, guru terbiasa berinteraksi dengan siswa di sekolah, dan metode pembelajaran jarak jauh membuat guru perlu waktu untuk beradaptasi dan beradaptasi. Mereka menghadapi perubahan baru, yang secara tidak langsung akan mempengaruhi kualitas hasil belajar.

Al Qalam: Jurnal Ilmiah Keagamaan dan Kemasyarakatan Vol. 16, No. 2

Maret - April 2022 
Ridhatullah Assya'bani, Muhammad Majdi : Pengembangan Model Pembelajaran Pasca Covid-19 Berdasarkan Pembelajaran Abad 21

Dampak selanjutnya yang ditemui guru adalah sekolah ditutup terlalu lama, yang membuat guru menjadi bosan. Jika mereka bisa berinteraksi dengan guru dan siswa lain di sekolah belum terbiasa dengan jaringan online ini, para guru juga akan kehilangan semangat sosialnya dan hanya bisa tinggal di dalam umah. Wabah Covid-19 telah memaksa para guru untuk menggunakan teknologi, jadi suka atau tidak suka, mereka harus belajar dan bersiap menggunakan teknologi untuk pengajaran jarak jauh. Setiap sekolah telah menyiapkan alat dan sistem pembelajaran jarak jauh, dan memberikan bimbingan teknis kepada guru agar mereka dapat menggunakan teknologi modern dalam pembelajarannya untuk meningkatkan kualitas siswa sekolah dasar. Kendala yang dihadapi guru adalah biaya tambahan.

Peningkatnya pembelian kuota internet, teknologi online perlu terkoneksi dengan internet dan jaringan kuota, sehingga penggunaan kuota internet akan semakin meningkat dan menambah beban biaya guru. Tentu saja, untuk beberapa bulan pembelajaran online, lebih banyak kuota akan dibutuhkan, otomatis akan meningkatkan biaya untuk pembelian kuota internet. ${ }^{14}$ Sebelum melaksanakan kegiatan rencana pembelajaran online, sebaiknya diberikan berupa saran dan pendapat kepada instansi terkait untuk mempersiapkan fasilitas penunjang, kemampuan dan pelatihan bagi siswa, guru dan orang tua. Tanpa persiapan yang tepat, kualitas pengajaran akan terpengaruh.

Tantangan perguruan tinggi selama wabah pandemi Covid ini dan permintaan akan pendidikan perguruan tinggi telah mengurangi dampaknya terhadap perguruan tinggi itu sendiri. Akibat banyaknya PHK akan berdampak pada berkurangnya sumber pendapatan keluarga, yang dapat mengurangi kekhawatiran masyarakat untuk tidak melanjutkan pendidikan atau menunda melanjutkan pendidikan hingga Tingkat minat yang lebih tinggi. Berdampak pada jumlah mahasiswa baru. Bagi siswa, hal ini akan mempengaruhi kemampuan siswa tertentu, seperti kemampuan membayar sumbangan pengembangan pendidikan (SPP).

Metode pengajaran telah mengubah bagaimana cara sistem online berbagai pendidikan sekolah dari sekolah dasar sampai perguruan tinggi, sebagian besar dalam pendidikan telah mengubah proses pengajaran yang semula tatap muka kini sudah sistem online. Bahkan, semua perguruan tinggi terpaksa menerapkan perkuliahan online, yang merupakan pilihan mendesak dan menjadi sistem utama dalam proses pengajaran. Bagi mahasiswa sulit melakukan penelitian lapangan dan pembinaan, sehingga tidak dapat lulus tepat waktu, dan hal ini juga dapat meningkatkan jumlah mahasiswa yang drop out (DO).

${ }^{14}$ Zulkifli dkk, Bekarya Bersama di Tengah Covid-19, Sulawesi Selatan, IAIN Parepare Nusantara 2020. Hlm. 331-332

Al Qalam: Jurnal Ilmiah Keagamaan dan Kemasyarakatan Vol. 16, No. 2

Maret - April 2022 
Ridhatullah Assya'bani, Muhammad Majdi : Pengembangan Model Pembelajaran Pasca Covid-19 Berdasarkan Pembelajaran Abad 21

Dalam kegiatan pembelajaran seperti ini ada juga masalah bagi para pelajar dimana terkendala dalam batas biaya untuk Internetan, salah satu penyebabnya adalah akibat berkurangnya pendapatan keluarga, dengan menggunakan metode pembelajaran online yang berkelanjutan, biaya internet yang sangat dibutuhkan dalam pembelajaran online menjadi beban. Kuota internet atau paket data yang dibeli untuk memenuhi permintaan Internet menjadi semakin tinggi. Dunia akademis tidak terbiasa menggunakan metode online. Terdapat kesulitan dalam menggunakan metode sistem online karena belum terbiasa dan dilatih untuk menggunakan sistem dan peralatan. Oleh karena itu, diperlukan dukungan tutorial tambahan untuk menyesuaikan dengan model pembelajaran online yang memadai dan efektif. Kurangnya kreativitas guru, belum lagi semua dosen dan mahasiswa menguasai teknologi, karena tingkat penguasaan teknologi masih sangat rendah. Fasilitas aplikasi dan perlengkapan belajar hanya terbatas pada laptop atau smartphone.

Gangguan sinyal dalam proses belajar mengajar sistem online, minimnya internet di daerah pemukiman, terkadang labil dan lemah, karena lokasi tempat tinggal masih jauh dari jangkauan sinyal seluler. Dengan demikian, kegiatan belajar online tidak dapat berjalan dengan lancar yang sesuai dengan harapan. Oleh karena itu, terdapat kesenjangan perbedaan kecepatan internet di berbagai wilayah. Seperti otang-orang di daerah perkotaan menikmati kecepatan Internet yang lebih cepat dari pada orang-orang di daerah tertinggal. Kejenuhan kuliah online oleh guru serta siswa. Jika Perkuliahan di lakukan dengan proses Jarak Jauh atau PJJ berlangsung lama, maka pembelajaran online akan membosankan. Jika bosan ini tidak dapat segera diatasi, maka akan mengakibatkan proses belajar mengajar yang tidak memuaskan dan efek belajar yang tidak sesuai dan tidak memuaskan. Kuliah sistem online tidak sesempurna pada kuliah berlangsung di kelas.

Pembelajaran online dapat dengan mudah mengirimkan informasi dalam berbagai situasi dan kondisi. Kegiatan pembelajaran dapat dilaksanakan secara efektif berdasarkan kreativitas guru dalam memberikan materi kepada siswa. Namun mengingat orang tua memiliki kemampuan untuk menyediakan fasilitas belajar online yang berbeda, pembelajaran online / online perlu dievaluasi dan disesuaikan dengan kondisi satuan pendidikan. Kuncinya adalah memaksimalkan kemampuan belajar siswa di bawah pandemi Covid-19.

Siswa belajar dalam konteks pandemi covid-19. langkah strategis yang harus diambil sekolah adalah: ${ }^{15}$

${ }^{15}$ Gusty. Sri, dkk, Belajar Mandiri Pembelajaran Daring di Tengah Pendemi Covid-19, Yayasan Kita Menulis, 2020. HIm. 161-162.

Al Qalam: Jurnal Ilmiah Keagamaan dan Kemasyarakatan Vol. 16, No. 2

Maret - April 2022 
Ridhatullah Assya'bani, Muhammad Majdi : Pengembangan Model Pembelajaran Pasca Covid-19 Berdasarkan Pembelajaran Abad 21

1. Kaji ulang tujuan pembelajaran yang ingin dicapai agar sekolah tetap rasional dan konsisten dengan situasi baru dan kondisi baru di bawah normal baru.

2. Menentukan sumber daya yang perlu dimiliki dan digunakan untuk mencapai tujuan baru yang telah ditetapkan.

3. Sesuai dengan mixed learning yang dirancang, petakan situasi dan situasi masing-masing guru dan siswa yang harus siap dengan model pembelajaran baru.

4. Mengevaluasi kesenjangan antara permintaan dan ketersediaan untuk mengembangkan strategi dan langkah-langkah operasional untuk segera menjembataninya.

5. Melalui terbangunnya berbagai hubungan kerja sama dengan pihak luar yang berkepentingan dengan pendidikan, langkah-langkah tersebut dilakukan secara kreatif.

Korelasi dalam konteks pandemi covid-19 dijabarkan pada model pembelajaran yang berorientasi pada abad 21 adalah sebagai berikut: ${ }^{16}$

1. Communication skill, pada model ini orientasi utamanya terletak pada kesempatan yang diberikan kepada siswa untuk menggunakan kemampuannya dalam mengutarakan ideide, baik dalam kegiatan diskusi dengan teman sebaya ataupun menyelesaikan masalah oleh gurunya. Pada model ini tidak dianjurkan guru yang memberikan tugas terlalu berlebihan sehingga melupakan adanya komunikasi dua arah.

2. Collaboration skill, pada model ini orientasinya adalah kemampuan dalam kerja sama kelompok dan kepemimpinan, beradaptasi dari peran dan tanggung jawab, bekerja secara produktif, empati, memaklumi kerancuan, dan menghormati perspektif berbeda. Pada model ini kolaborasi atau berbaur adalah kunci utama yang dapat diciptakan pada masa pendemi dengan tugas pembelajaran yang berhubungan dengan hubungan kerjasama antara anggota keluarga atau teman sejawat tempat tinggalnya.

3. Critical thinking and problem solving skill, pada model ini orientasi utamanya adalah siswa dapat memberdayakan kemampuannya untuk dapat menyelsaikan masalah yang dihadapi secara mandiri, siswa juga memiliki kemampuan untuk menyusun dan mengungkapkan, menganalisis, dan menyelesaikan masalah yang dihadapi. Pada model ini guru dapat menggunakan pembelajaran HOTS (Higher Order Thingking Skills) yang mana siswa distimulasi dalam berpikir kritis dan menyelesaikan masalah lewat pengerjaan tugas atau proyek.

Situasi yang terjadi dan setelah pandemi ini menyadarkan dunia pendidikan bukan satusatunya tempat belajar Kapan pun, dimanapun. Selain itu, situasi ini juga dikonfirmasikan kepada

${ }^{16}$ M.Hosnan, Pendekatan Saintifik dan Kontekstual dalam Pembelajaran Abad 21, (Bogor: Ghalia Indonesia, 2014), hlm. 87.

Al Qalam: Jurnal Ilmiah Keagamaan dan Kemasyarakatan Vol. 16, No. 2

Maret - April 2022 
Ridhatullah Assya'bani, Muhammad Majdi : Pengembangan Model Pembelajaran Pasca Covid-19 Berdasarkan Pembelajaran Abad 21

guru maupun dosen Mereka bukan satu-satunya sumber belajar, siswa dapat menemukan sumber lain memadai. ${ }^{17}$ Selain itu, cara berpikir pembelajaran dari pusat guru juga mengalami perubahan Menjadi pusat pembelajaran siswa. Untuk hal itu, opsi pembelajaran Mengambang. Desain pembelajaran berkaitan dengan empat aspek dasar yaitu metode, strategi, Teknologi dan media dalam kegiatan pembelajaran. Empat hal ini penting Hubungan antara pandemi pasca Covid-19. Karena semua pembelajaran online (pembelajaran Dari rumah), maka ide memilih kesesuaian dengan keadaan sekarang. Mempertimbangkan kondisi tersebut, pilihan desain dan aplikasi sangat menentukan keberhasilan Belajar.

Penelitian ini menggunakan metode studi pustaka dan survei. Penelitian perpustakaan adalah penelitian yang menggunakan berbagai bahan seperti file dokumen, buku, sejarah, berita, dan lain sebagainya, untuk mengumpulkan informasi dan data. Pada saat yang sama, menurut para ahli penelitian perpustakaan, penelitian teoritis, literatur referensi dan Literatur ilmiah lain yang berkaitan dengan budaya, nilai dan norma yang berkembang dalam lingkungan sosial yang diteliti, data dikumpulkan dari artikel di jurnal online. ${ }^{18}$

\section{KESIMPULAN}

Termasuk dalam rencana pembelajaran adalah model pembelajaran yang relevan diterapkan sesuai dengan kebutuhan kelas. Model pembelajaran yang diterima secara umum perlu menciptakan keunikan dan perubahan dari model tersebut. Pembelajaran virtual digunakan untuk menyelesaikan masalah. Dengan cara ini, siswa dapat memiliki materi pembelajaran yang telah di buat dalam kegiatan proses pembelajaran yang telah di tentukan dan di siapkan. Melalui pembelajaran virtual semacam ini, siswa dapat dengan mudah memperoleh buku teks (materi) sendiri, atau jika dirasa perlu, siswa dapat bertanya ke mesin pencari (seperti google) atau pembelajaran yang dibantu oleh sumber belajar lain (seperti siswa atau pakar lain). Ini terkait dengan sistem penilaian dan juga dapat diselesaikan secara online. Melalui sistem penilaian ini, siswa dapat menemukan nilainya setiap saat.

Pembelajaran yang menggunakan konsep pembelajaran virtual kurang bersifat tatap muka langsung, yaitu sistem pembelajaran yang mengandalkan konten yang dapat diakses publik yang telah disediakan atau dapat diperoleh dari sumber lain dan berbasis web. Konsep pembelajaran virtual tidak digunakan untuk menggantikan pembelajaran tatap muka, tetapi untuk menggabungkan pembelajaran tatap muka dengan konsep online. Dengan adanya pembelajaran

\footnotetext{
${ }^{17}$ Marbun. Purim, Disain Pembelajaran Online Pada Era Dan Pasca Covid-19 Online Learning Design In Era And Post Covid-19, CSRID Journal, Vol. 12 No. 2 Juni 2020. Hlm. 133.

${ }^{18}$ Astini. Ni Komang Suni, Tantangan Dan Peluang Pemanfaatan Teknologi Informasi Dalam Pembelajaran Online Masa Covid-19, jurnal ilmu pendidikan, 2020. Hlm. 244.
}

Al Qalam: Jurnal Ilmiah Keagamaan dan Kemasyarakatan Vol. 16, No. 2

$$
\text { Maret - April } 2022
$$


Ridhatullah Assya'bani, Muhammad Majdi : Pengembangan Model Pembelajaran Pasca Covid-19 Berdasarkan Pembelajaran Abad 21

virtual, selain dapat meningkatkan efektivitas dan efisiensi pendidikan, kualitas pembelajaran juga akan meningkat. Dalam aplikasi pembelajaran virtual, komponen yang disebut sebagai struktur yang digunakan untuk menyempurnakan Merupakan bagian integral dari siswa, guru dan sumber belajar untuk mencapai tujuan pembelajaran. Prinsip utama pembelajaran virtual adalah otoritas dan kolaborasi. Siswa menentukan materi, waktu mengakses sumber belajar, waktu yang dimiliki, media yang digunakan, prinsip kewenangan, dan langkah-langkah pembelajaran untuk mencapai tujuan pembelajaran. Prinsip kolaborasi menuntut siswa untuk berinteraksi dan komunikasi dengan siswa lain, guru atau tutor, dan sumber belajar lain yang disediakan.

Pembelajaran Abad 21 yang relevan Pasca Covid-19 adalah 1) Communication skill, bagaimanapun pembelajarannya jangan melupakan hubungan komunikasi dua arah bukan satu arah. 2) Collaboration skill, penekanan hubungan kerjasama antara anggota keluarga atau teman sejawat tempat tinggalnya. 3) Critical thinking and problem solving skill, pembelajaran HOTS (Higher Order Thingking Skills).

\section{DAFTAR PUSTAKA}

Albinur Limbong, Pengaruh Model Pembelajaran Daring Akibat Pandemi Covid-19 Terhadap Prestasi Belajar Mahasiswa UNAI pada Semester Genap 2019/2020, Jurnal TeIKa, Volume 10, Nomor 2, Oktober 2020.

Astini. Ni Komang Suni, Tantangan Dan Peluang Pemanfaatan Teknologi Informasi Dalam Pembelajaran Online Masa Covid-19, jurnal ilmu pendidikan, 2020.

Budi Indrawat, Tantangan Dan Peluang Pendidikan Tinggi Dalam Masa Dan Pasca Pandemi Covid-19, Jurnal Kajian Ilmiah (JKI) e-ISSN: 2597-792X, ISSN: 1410-9794 Edisi Khusus No. 1 Juli 2020.

Daryanto dan Syaiful Karim, Pembelajaran Abad 21, Yogyakarta: Gava Media, 2017.

Denok Sunarsi dkk, Jurnal Implementasi Pembelajaran Online Dalam Masa Pandemik Covid 19, 2020)

Destriana Widyaningrum. Silvi, dkk, Jurnal Pentingnya Penyusunan Jadwal Pelajaran Dalam Proses Pembelajaran Di Tengah Pandemi Covid-19, 2020.

Gusty. Sri, dkk, Belajar Mandiri Pembelajaran Daring di Tengah Pendemi Covid-19, Yayasan Kita Menulis, 2020.

Indrawat. Budi, Tantangan Dan Peluang Pendidikan Tinggi Dalam Masa Dan Pasca Pandemi Covid-19, Jurnal Kajian Ilmiah (JKI) e-ISSN: 2597-792X, ISSN: 1410-9794 Edisi Khusus No. 1, Juli 2020.

Jamaludin dkk, Belajar dari Covid-19 Perspektif Sosiologi, Budaya, Hukum kebijakan dan Pendidikan, Mesdan, 2020.

Jamaludin dkk, Belajar dari Covid-19 Perspektif Sosiologi, Budaya, Hukun kebijakan dan Pendidikan, Mesdan,2020.

Al Qalam: Jurnal Ilmiah Keagamaan dan Kemasyarakatan Vol. 16, No. 2

Maret - April 2022 
Ridhatullah Assya'bani, Muhammad Majdi : Pengembangan Model Pembelajaran Pasca Covid-19 Berdasarkan Pembelajaran Abad 21

Limbong. Albinur, Pengaruh Model Pembelajaran Daring Akibat Pandemi Covid-19 Terhadap Prestasi Belajar Mahasiswa UNAI pada Semester Genap 2019/2020, Jurnal TeIKa, Volume 10, Nomor 2, Oktober 2020.

M.Hosnan, Pendekatan Saintifik dan Kontekstual dalam Pembelajaran Abad 21, Bogor: Ghalia Indonesia, 2014.

Marbun. Purim, Disain Pembelajaran Online Pada Era Dan Pasca Covid-19 Online Learning Design In Era And Post Covid-19, CSRID Journal, Vol. 12 No. 2 Juni 2020.

Mutmainnah, dkk, Jurnal Paradigma Model Experience Of Learning.

Ni Komang Suni Astini, Tantangan Dan Peluang Pemanfaatan Teknologi Informasi Dalam Pembelajaran Online Masa Covid-19, jurnal ilmu pendidikan, 2020.

Nur Atiqoh Bela Dina. Lia, Respon Orang Tua Terhadap Pembelajaran Daring Pada Masa Pandemi Covid-19, THUFULI: Jurnal Ilmiah Pendidikan, Islam Anak Usia Dini, Volume 2 Nomor 1 Tahun 2020.

Pujilestari. Yulita, Dampak Positif Pembelajaran Online Dalam Sistem Pendidikan Indonesia Pasca Pandemi Covid-19, Volume 4 Nomor 1, 2020.

Purim Marbun, Disain Pembelajaran Online Pada Era Dan Pasca Covid-19 Online Learning Design In Era And Post Covid-19, CSRID Journal, Vol. 12 No. 2 Juni 2020.

Silvi Destriana Widyaningrum dkk, Jurnal Pentingnya Penyusunan Jadwal Pelajaran Dalam Proses Pembelajaran Di Tengah Pandemi Covid-19, 2020.

Sri Gusty dkk, Belajar Mandiri Pembelajaran Daring di Tengah Pendemi Covid-19, Yayasan Kita Menulis, 2020.

Sunarsi. Denok, dkk, Jurnal Implementasi Pembelajaran Online Dalam Masa Pandemik Covid $19,2020$.

Wardhana. Dharendra, Kajian Kebijakan dan Arah Riset Pasca-Covid-19, The Indonesian Journal of Development Planning Volume IV No. 2 - Juni 2020.

Widya Sari dkk, Jurnal Analisis Kebijakan Pendidikan Terkait Implementasi Pembelajaran Jarak Jauh Pada Masa Darurat Covid 19, 2020.

Yulita Pujilestari, Dampak Positif Pembelajaran Online Dalam Sistem Pendidikan Indonesia Pasca Pandemi Covid-19, Volume 4 Nomor 12020.

Zulkifli dkk, Bekarya Bersama di Tengah Covid-19, Sulawesi Selatan, IAIN Parepare Nusantara 2020.

Al Qalam: Jurnal Ilmiah Keagamaan dan Kemasyarakatan Vol. 16, No. 2

Maret - April 2022 